\title{
УДК: 004.621.4
}

\author{
Микола Миколайович Радченко ${ }^{1}$ \\ Олексій Вікторович Драглюк ${ }^{1}$ \\ Михайло Михайлович Коротков ${ }^{1}$ \\ Олександр Серхійович Бідний ${ }^{2}$
}

${ }^{1}$ Військовий інститут телекомунікацій та інформатизації ім. Героӥв Крут, Київ, Украӥна

${ }^{2}$ Командування Військ зв'язку та кібербезпеки Збройних Сил Украӥни, Київ, Украйна

\section{ВИЗНАЧЕННЯ ЧИСЕЛЬНОГО ЗНАЧЕННЯ УЗАГАЛЬНЕНОГО ПОКАЗНИКА ЦІННОСТІ ІНФОРМАЦІЇ З ТОЧКИ ЗОРУ Ї̈ БЕЗПЕКИ}

В розрізі забезпечення захищеності інформації в конкретних умовах виникає ряд труднощів, пов'язаних з тим що обрані властивості інформащії різнорідні і не співмірні, невизначені області допустимих значень характеристик та властивостей захисту, які $\epsilon$ похідним від того що захищається $і$ напряму залежать від властивостей самої інформацї, які у свою чергу задаються власником інформації. Більш того, представляє інтерес з метою визначення вартісних величин захисту, визначення кількісних показників властивостей захисту.

Метрики інформаційної безпеки у відповідних методиках, які засновані на підходах верифікації та ризик-орієнтування недостатньо інформативні, так як враховують лише об'єктивні аспекти безпеки, абсолютно ігноруючи суб'єктивні. Вони не дозволяють виробити обтрунтовані судження про стан конфіденційності, цілісності і доступності інформації і рівні інформаційної безпеки в цілому. Узв'язку з цим автори пропонують підхід до визначення чисельного значення узагальненого показника цінності інформації на основі логіко-лінгвістичної моделі оцінки властивостей, які характеризують цей показник, i методу попарних порівнянь, який використовується для визначення чисельних значень коефіцієнтів важливості обраних властивостей інформації.

У даній роботі пропонується підхід щуодо рімення завдань кількісної оијнки різнорідних властивостей інформації $і$ коефіцієнтів ї̈ важливості в інтересах захисту інформацї та визначення впливу властивостей інформації, які задаються власником системи захисту інформації на узагальнений показник иінності інформації. При цььому, для оцінки чисельних значень розглянутих властивостей інформачї̈ пропонується використання апарату теорії нечітких множин, а визначення відповідних коефічієнтів важливості здійснюється за допомогою методу аналізу ієрархій Сааті.

Ключові слова: властивість інформації; узагальнений показник цінності інформації; коефіцієнт важливості.

\section{Вступ}

У теперішньому світі фахівці захисту інформації направляють свої зусилля на формування та розвиток безпечного середовища при інформаційному обміні. Ступінь захищеності інформації визначається якістю іiі захисту, сукупністю властивостей i характеристик інформаційної послуги, які дозволяють рівню захисту інформації відповідати встановленим вимогам.

Постановка проблеми. При забезпеченні захищеності інформації в конкретних умовах виникає ряд труднощів, пов'язаних 3 відсутністю як переліку іï властивостей і характеристик, так i області їх допустимих значень. Очевидно, що на властивості чи характеристики захисту (оскільки вони є похідними від того, що підлягає захисту) на пряму впливають властивості самої інформації, які задаються власником інформації.

Обгрунтований вибір необхідного рівня захищеності інформації 3 відомих причин $\epsilon$ складним завданням, тому доцільно виходити 3 підходу, що такий рівень може бути адекватно оцінений лише ступенем досягнення цілей захисту інформації. Природньо, що метою діяльності щодо захисту інформації $\epsilon$ встановлений статус іiі зберігання, обробки та використання. 3 цього випливає, що, по-перше, поняття захищеності інформації має певний набір властивостей i характеристик статусу іiі зберігання, обробки та використання i, по-друге, такий набір властивостей i характеристик повинен бути оцінюваним. 
Разом 3 тим неоднозначність самого поняття „інформація”, різноманіття іiі властивостей, складність i організаційна природа діяльності щодо ii захисту а також широкий діапазон i динаміка користувацьких вимог до такого роду діяльності привели до появи значної кількості різних змінних, слабо пов'язаних або не пов'язаних між собою показників, що характеризують властивості забезпечення захищеності інформації [1].

Виходячи 3 цього автори вважають актуальним завдання, яке полягає у формуванні підходу вибору та визначення величин чисельних значень властивостей інформації, що дозволило б іiі власнику в достатній мірі об’єктивно визначати цінність $з$ точки зору іiї захисту і тим самим більш раціонально підійти до вирішення завдання оцінки рівня захисту інформації а також фінансових затрат на захист інформації.

Аналіз останніх досліджень і публікацій.

Питання оцінки захисту інформації знайшли своє відображення у роботах багатьох дослідників. Особливості матеріалів, наданих ними у своїх статтях [1 - 6], коротко наведемо нижче.

В статті [1] зазначено що об'єктивні властивості забезпечення захищеності інформації $€$ величинами, (співвідношеннями), які не змінюються при тих або інших перетвореннях для умов діяльності по захисту інформації, архітектури систем захисту інформації та технологій захисту, які використовуються (обсяг інформації, що захищається, час виконання процедури захисту) та суб'єктивні властивості забезпечення захищеності інформації - здатність послуги захисту інформації відповідати певним вимогам призначеним користувачем (конфіденційність, цілісність, доступність інформації, своєчасність реалізації функцій захисту інформації тощо). В роботі обгрунтоване завдання пошуку показника, що поєднував би в собі як об'єктивні, так і суб'єктивні властивості забезпечення захищеності інформації та спроба аналітично їх взаємо пов'язати у найбільш загальний i вживаний показник захищеності інформації. В кінцевому підсумку для визначення задоволення або незадоволення потреб у захисті інформації пропонується використовувати показник конфіденційності інформації в умовах своєчасної реалізації функцій захисту інформації при заданих рівнях їі цілісності та доступності. В роботі припущено, що таким чином реалізується принцип однорідності уявлення характеристик процесів захисту інформації, який може бути підставою для уніфікації опису відповідних механізмів захисту інформації та дасть кількісне представлення процесів захисту, хоча не наведено 3 допомогою якого математичного апарату можливо виконання таких завдань.
В роботі [2] піднімається проблематика стандартизації вимог до якості захисту інформації, яка полягає у відсутності формальних або раціональних методів об'єктивного обгрунтування необхідного i достатнього набору оціночних показників і вимог до їх значень, що породжує неадекватне сприйняття користувачами послуги захисту інформації. Для вирішення проблеми оцінки якості захисту інформації, в автоматизованих комплексах фізичного захисту пропонується розробити та обгрунтувати: множину показників якості; вимоги до областей допустимих значень цих показників з точки зору предметної області; розробити методики вимірювання та оцінки якості, що стане основою для синтезу системи показників для оцінки захищеності інформаційних ресурсів автоматизованих комплексів фізичного захисту. 3 огляду на те, що міжнародні стандарти ISO 9000 (в статті захисту інформації в автоматизованих комплексах фізичного захисту) використовують три групи показників якості послуги захисту: технічні, суб'єктивні та економічні, автор пропонує в якості критерію класифікації використовувати спосіб вимірювання, а саме: об'єктивний спосіб вимірювання, що являє собою інструментальний або розрахунковий вимір властивості предмета або послуги; який дає дві сторони об'єктивних якостей захисту інформації (підмножини технічних і економічних показників); суб'єктивний спосіб вимірювання якості захисту інформації, що передбачає вимірювання і оцінку якості захисту інформації, які проводяться за допомогою, так званих, суб'єктивних показників безпосередньо користувачем і без застосування будь-яких пристосувань, інструментів або обчислювальних методів (створюються множини показників, які похідні від об'єктивних - як показники першого роду, i другого роду обумовлених організаційною природою систем захисту, властивих тільки такого роду системам i які не описуються, не оцінюються і не мають взаємозв'язку 3 об'єктивними (технічними) показниками). Однак в статті не розглянутий вплив на властивості послуги захисту інформації від цінності самої інформації з точки зору іiі захисту, яка задається користувачем, що у свою чергу не дає відповідь на питання відповідності рівня захисту інформації рівню їі цінності.

В роботі [3] констатується, що метрики інформаційної безпеки (далі - ІБ) у відповідних методиках, які засновані на підходах верифікації та ризик-орієнтування недостатньо інформативні, так як враховують лише об'єктивні аспекти безпеки, абсолютно ігноруючи суб'єктивні. Вони не дозволяють виробити обгрунтовані судження про стан конфіденційності, цілісності і доступності інформації і рівні ІБ організації у цілому. У зв'язку 3 цим автори пропонують 
розробити методичний апарат оцінки ІБ організації 3 урахуванням об'єктивних і суб'єктивних аспектів безпеки. На підставі стандарту ISO/IEC TR 15443-1:2005, де вперше вводиться суб'єктивна категорія IT-безпеки “довіра" разом із методом його забезпечення а також стандартів серії ISO 9000, ISO/IEC 154081:2009 i стандарту SSE-CMM (ISO/IEC 21827:2008), які описують специфіку забезпечення довіри для конкретної стадії життєвого циклу об'єкта довіри пропонується підхід до оцінки ІБ на основі критерію впевненості у тому, що в організації реалізується прийнята політика безпеки. Оцінка впевненості включає оцінку довіри до ІБ організації та моделі оцінки довіри і осіб із базовими знаннями щодо предметної діяльності, які проводили таку оцінку і оцінку знань щодо загроз. Як показник впевненості використовується показник корисності як значення узагальненої функції бажаності за шкалою Харрінгтона. Запропонований підхід до оцінки ІБ організації є досить простим в реалізації i може бути використаний в якості базового для розробки відповідних методик оцінки ІБ організацій різних форм власності але не дає чіткого розуміння щодо оцінки властивостей інформації, які формують ії цінність з точки зору іï захисту та їі вплив на рівень захисту.

Цікавим, в розрізі тематики статті, є підхід, визначений в роботах [4 - 6]. Передбачається формування і обчислення узагальненого показника цінності інформації як сукупності властивостей інформації, які характеризують іiі цінність за прийняттям управлінських рішень в інтересах деякої діяльності. Констатується необхідність дослідження різнорідних властивостей інформації, що становлять іiї цінність, і в тому числі кількісної оцінки цих властивостей залежно від характеристик структурних елементів каналів зв'язку при проходженні інформації через нього. Узагальнений показник цінності інформації пропонується використовувати в якості критерію для оцінки характеристик середовища передачі інформації.

Таким чином, визначимо, що публікації в даній предметній області хоч і дають часткові відповіді на запитання, пов'язані із оцінюванням ефективності системи ІБ, але не дають відповіді на запитання: чим обумовлена величина узагальненого показника цінності інформації 3 точки зору іiі захисту, у якій ступені зміни таких властивостей інформації як конфіденційність, цілісність, доступність впливають на узагальнений показник її цінності.

Отже актуальною $\epsilon$ постановка задачі формування підходу визначення чисельних значень властивостей інформації з точки зору іiі безпеки при визначенні узагальненого показника цінності інформації в інтересах захисту інформації.

Метою статті є формування підходу визначення чисельних значень властивостей інформації з точки зору іiї безпеки при визначенні узагальненого показника цінності інформації.

\section{Виклад основного матеріалу дослідження.}

В якості основних властивостей, які характеризують цінність інформації для забезпечення діяльності [4] розглядаються: достовірність, повнота, конфіденційність, скритність, своєчасність, адекватність, релевантність, толерантність, зрозумілість, розбірливість. Таким чином множина С властивостей інформації має вигляд:

$$
\mathrm{C}=\{\mathrm{ci} / \mathrm{i}=1,2,3, \ldots, \mathrm{I}\},
$$

де $\mathrm{c}_{\mathrm{i}}$ - i-та властивість інформації, I - кількість обраних властивостей, які актуальні для визначеного виду діяльності.

Як наведено в статті [7] обираємо важливі 3 точки зору захисту інформації такі властивості як:

конфіденційність - властивість інформації, яка полягає в тому, що інформація не може бути отримана неавторизованим користувачем або процесом;

цілісність - властивість інформації, яка полягає в тому, що інформація не може бути модифікована неавторизованим користувачем або процесом;

доступність - властивість ресурсу системи (комп'ютерної системи, послуги, об'єкта комп'ютерної системи, інформації), яка полягає в тому, що користувач або процес, який володіє відповідними повноваженнями, може використовувати ресурс відповідно до правил, встановлених політикою безпеки, не очікуючи довше заданого проміжку часу, тобто коли він знаходиться у вигляді, необхідному користувачеві, в місці, необхідному користувачеві, і в той час, коли він йому необхідний.

Обрані властивості інформації різнорідні і не співмірні, вони можуть бути взаємопов'язані через узагальнений показник цінності інформації [7], який забезпечує предметну діяльність з точки зору забезпечення безпеки інформації.

Аналітично взаємозв'язок обраних властивостей інформації стосовно деякого повідомленням х 3 їх множини $\mathrm{x} \in\{\mathrm{X}\}$ можливо представити у вигляді узагальненого показника цінності [7]:

$$
\mathrm{Z}(\mathrm{x})=\sum_{\mathrm{i}=1}^{\mathrm{I}} \mathrm{wi}(\mathrm{x}) \mathrm{c}_{\mathrm{i}}(\mathrm{x}),
$$

де $\mathrm{c}_{\mathrm{i}}(\mathrm{x})$ - набір вимірних показників властивостей інформації для повідомлення $\mathrm{x},(\mathrm{i}=1,2,3) ; \mathrm{w}_{\mathrm{i}}(\mathrm{x})$ вагові коефіцієнти, що характеризують важливість відповідних властивостей інформації з точки зору iii безпеки, і які визначаються експертним шляхом [8]; I - кількість властивостей інформації, які 
прийняті для визначення цінності інформаційного повідомлення з точки зору його безпеки.

Логіко-лінгвістична модель для чисельної оиінки властивостей інформації.

Завдання визначення оцінки властивостей інформації можливо віднести до класу задач, які є надмірно складними або нечітко визначеними у випадку проведення їх до точного математичного аналізу. Тому, як наведено в роботі [9] доцільно застосовувати методи логіко-лінгвістичного (семантичного) моделювання, які базуються на “м'яких" обчислювальних розрахунках і здатні якісно описувати та вивчати процеси, системи та явища, які слабо структуруються.

Головною перевагою методів логіколінгвістичного моделювання є те, що мовні засоби, які використовуються в “м'яких" розрахунках, мають більші можливості по формалізації реальних ситуацій у порівнянні із традиційними математичними мовами.

Моделі, побудовані на основі “м'яких” мовних засобів, $є$ семантичними або логіколінгвістичними i характеризуються наступними основними специфічними особливостями:

- змінні, які використовуються в таких моделях, як правило, не кількісні, а якісні (семантичні, т. т. їх значеннями є слова і терміни природньої мови, а не числа);

- змінні взаємопов'язані між собою не математичними залежностями чи рівняннями, а мовно, з використанням виразів і фраз природньої мови;

- оцінка ефективності визначається не математичними формулами, а описується 3 допомогою якісних пропозицій та рекомендацій по неприпустимість, бажаність чи перевагу того чи іншого варіанту рішення.

Таким чином в якості одного із способів вирішення завдання визначення чисельних значень властивостей інформації доцільно використати лінгвістичний підхід. В рамках цього підходу кожен показник, що характеризує властивість інформації $\mathrm{c}_{\mathrm{i}}$, представляється деякою лінгвістичною змінною $\mathrm{V}_{\mathrm{i}}$, яка введена деякою безрозмірною величиною $\mathrm{V}_{\min } \leq \mathrm{V} \leq \mathrm{V}_{\max }$.

Формально лінгвістичні змінні можливо визначати виразом:

$$
<\beta, \mathrm{V}, \mathrm{D}>
$$

де $\beta$ - найменування лінгвістичної змінної; $\mathrm{V}=$ $\left\{\mathrm{V}_{1}, \ldots \mathrm{V}_{\mathrm{i}}, \ldots \mathrm{V}_{\mathrm{I}}\right\}$ - базова терм-множина, або множина значень лінгвістичних змінних, які представляють собою найменування нечітких змінної, D - область визначення нечітких змінних $\mathrm{i}$ $\epsilon$ чіткою множиною чисельних значень.

У Таблиці 1 наведені значення елементів виразу (2) для лінгвістичних змінних конфіденційність $\mathrm{c}_{1}$, цілісність $\mathrm{c}_{2}$, доступність $\mathrm{c}_{3}$.

Таблиця 1

Елементи виразу для лінгвістичних змінних конфіденційність $c_{1}$, цілісність $c_{2}$, доступність $c_{3}$.

\begin{tabular}{|c|c|c|c|c|c|c|}
\hline \multirow{2}{*}{$\beta$} & \multicolumn{5}{|c|}{ Значення нечітких змінних } & \multirow{2}{*}{$\mathrm{D}$} \\
\hline & $\mathrm{V}_{1}$ & $\mathrm{~V}_{2}$ & $\mathrm{~V}_{3}$ & $\mathrm{~V}_{4}$ & $\mathrm{~V}_{5}$ & \\
\hline $\begin{array}{c}\text { Конфіденційність } \\
\text { інформації с }{ }_{1}\end{array}$ & $\begin{array}{c}\text { Дуже } \\
\text { низька }\end{array}$ & Низька & Середня & Висока & $\begin{array}{c}\text { Дуже } \\
\text { висока }\end{array}$ & $0-100$ \\
\hline $\begin{array}{c}\text { Цілісність } \\
\text { інформації с }{ }_{2}\end{array}$ & $\begin{array}{l}\text { Дуже } \\
\text { низька }\end{array}$ & Низька & Середня & Висока & $\begin{array}{l}\text { Дуже } \\
\text { висока }\end{array}$ & $0-100$ \\
\hline $\begin{array}{l}\text { Доступність } \\
\text { інформації с } 3\end{array}$ & $\begin{array}{l}\text { Дуже } \\
\text { низька }\end{array}$ & Низька & Середня & Висока & $\begin{array}{l}\text { Дуже } \\
\text { висока }\end{array}$ & $0-100$ \\
\hline
\end{tabular}

Нечіткі змінні, в свою чергу, як наведено в роботі [10] можливо визначити кортежом

$$
<\mathrm{V}_{\mathrm{i}}, \mathrm{D}, \hat{\mathrm{V}}_{\mathrm{i}}>\text {, }
$$

де $\mathrm{V}_{\mathrm{i}}$ - найменування нечіткої змінної, $\mathrm{V}_{\mathrm{i}} \in\{\mathrm{V}\}$; $\mathrm{D}=\left\{\mathrm{D}_{\mathrm{i}}\right\}$ - область $\dddot{1 і ̈ ~ в и з н а ч е н н я, ~ а б о ~ у н і в е р с а л ь н а ~}$ множина; $\hat{V}_{\mathrm{i}}=\left\{\mu_{\mathrm{v}}, \mathrm{D}\right\}-$ нечітка множина спроектована на множину $\mathrm{D}$, що описує обмеження на можливі числові значення нечіткої змінної. $\mu_{\mathrm{v}}: \mathrm{D}$ - функція належності нечіткої множини $\mathrm{V}$ (відображення множини D в одиничному інтервалі $[0,1])$.

На Рис. 1 наведено приклад представлення графічної інтерпретації для лінгвістичної змінної “Конфіденційність інформації $\mathrm{c}_{1}$ ”. Аналогічно можливо вивести представлення для властивостей $\mathrm{c}_{2}, \mathrm{c}_{3}$.
Множина значень нечітких змінних $\{\mathrm{V}\}$ i області визначення чіткої множини $\{\mathrm{D}\}$, а також вид функції приналежності $\mu_{\mathrm{v}}$ визначаються експертним шляхом [10] стосовно до виду діяльності, яка оцінюється експертами (у нашому випадку - 3 точки зору безпеки інформації) і дасть змогу отримувати чисельні значення властивостей інформації $\mathrm{c}_{\mathrm{i}}$.

Таким чином запропонована формалізація нечітких понять i відносин забезпечується введенням відповідних нечітких і лінгвістичних змінних, нечіткої множини і їх взаємозв'язків. Це дозволяє, з одного боку, забезпечити перехід від словесних описів властивостей інформації до числових, а з іншого - дає можливість виробляти числову оцінку актуальності досліджуваної властивості інформації для узагальненого показника їі цінності. 


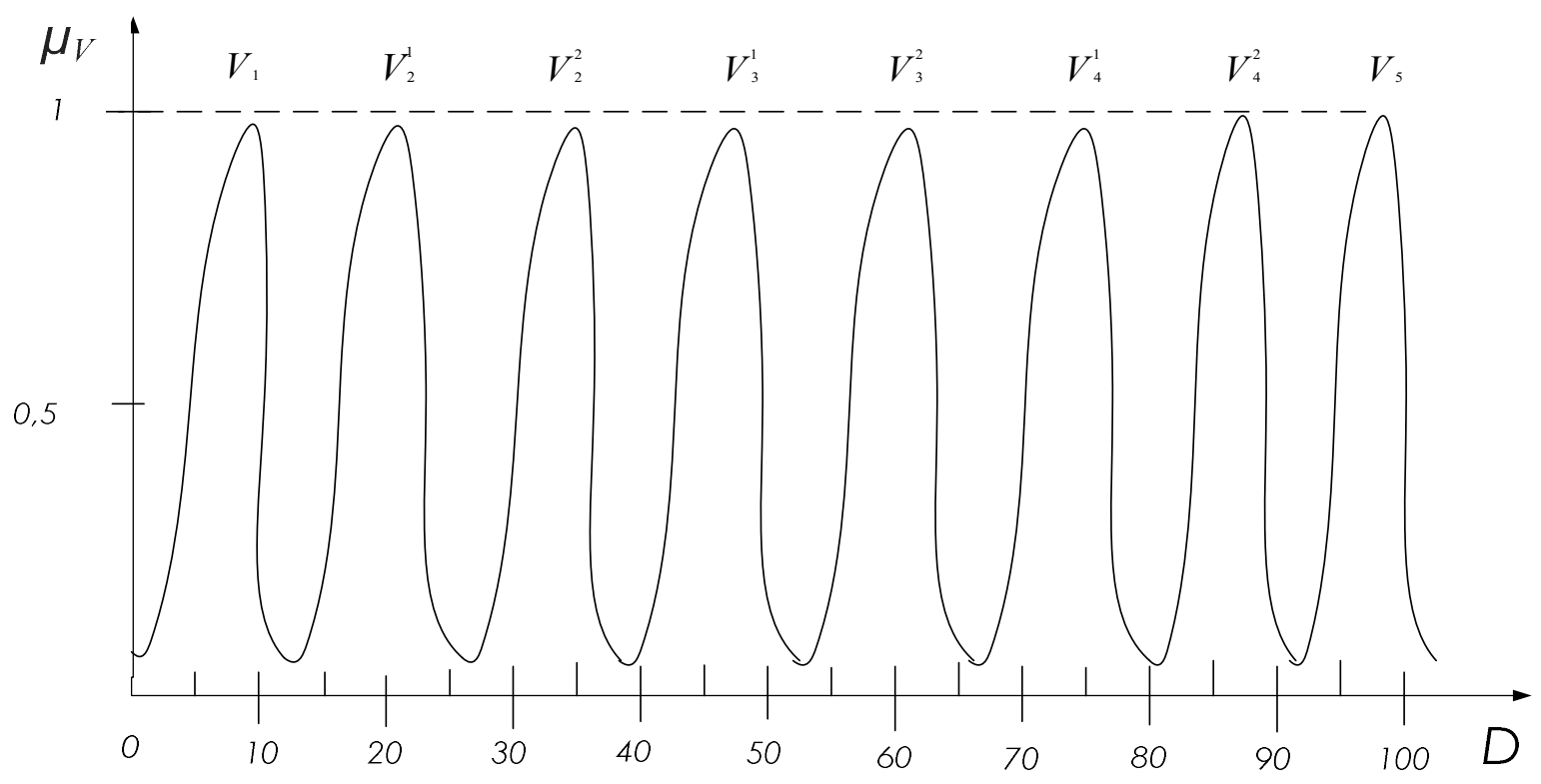

Рис. 1 Приклад представлення функції приналежності лінгвістичної змінної “Конфіденційність інформації с ${ }_{1} "$

Коефіцієнти важливості властивостей інформації можливо визначити методом Сааті із залученням експертів шляхом присвоєння лінгвістичних значень експертних оцінок пріоритетних критеріїв коефіцієнтів важливості $\mathrm{W}_{\mathrm{i}}(\mathrm{x})$ у формулі (1), де побудова самої матриці $\mathrm{W}=$ $\left(\mathrm{w}_{\mathrm{ij}}\right)$ попарних порівнянь для цих коефіцієнтів можлива з урахуванням правила:

1 - якщо критерії однакові;

5 - якщо критерій переважає істотно більше;

9 - якщо критерій переважає абсолютно більше.

Для прикладу, як наведено в роботі [11] обчислення коефіцієнтів $\mathrm{W}_{\mathrm{i}}$ можна здійснити методом парного порівняння критеріїв в наступному порядку:

1. Будується квадратна матриця парного порівняння критеріїв розмірністю $\mathrm{n}$, яка заповнюється коефіцієнтами $\mathrm{k}_{\mathrm{ij}}$, де $\mathrm{i}=1, \ldots \mathrm{n}, \mathrm{j}=1$, ... n, які показують перевагу критерію $\mathrm{K}_{\mathrm{i}}$ по відношенню над критерієм $\mathrm{K}_{\mathrm{j}}$. Значення вихідних коефіцієнтів $\mathrm{k}_{\mathrm{ij}}$ залежать від підходу до парного порівняння критеріїв, який застосовується;

2. Обчислюються показники важливості кожного 3 критеріїв $\mathrm{k}_{\mathrm{i}}$ за формулою:

$$
\mathrm{k}_{\mathrm{i}}=\sum_{\mathrm{j}=1}^{\mathrm{n}} \mathrm{k}_{\mathrm{ij}}
$$

де $\mathrm{i}=1, \ldots \mathrm{n}$.

3. Обчислюється сумарний показник важливості всіх критеріїв kс за формулою:

$$
\mathrm{k}_{\mathrm{c}}=\sum_{\mathrm{i}=1}^{\mathrm{n}} \mathrm{k}_{\mathrm{i}}
$$

4. Обчислюються вагові коефіцієнти критеріїв $\mathrm{W}_{\mathrm{i}}$ за формулою:

$$
\mathrm{W}_{\mathrm{i}}=\frac{\mathrm{ki}_{\mathrm{i}}}{\mathrm{k}_{\mathrm{c}}}
$$

де $\mathrm{i}=1, \ldots \mathrm{n}$.

5. Перевіряється виконання умови нормування критеріїв за формулою:

$$
\sum_{i=1}^{n} W_{i}=1 .
$$

При умові $\mathrm{w}_{\mathrm{ji}}=\left(\mathrm{w}_{\mathrm{ij}}\right)^{-1}$ матриця $\mathrm{W}=\left(\mathrm{w}_{\mathrm{ij}}\right)$ для властивостей інформаціі, обраних вище, 3 урахуванням критеріїв їх пріоритетних оцінок матиме вигляд:

$$
\mathrm{W}=\left\|\begin{array}{ccc}
1 & 5 & 9 \\
0,2 & 1 & 5 \\
0,111 & 0,2 & 1
\end{array}\right\|
$$

Обчислені коефіцієнти $\mathrm{w}_{\mathrm{i}}$ приймуть такі значення: $\mathrm{w}_{1}=0,666 ; \mathrm{w}_{2}=0,275 ; \mathrm{w}_{3}=0,058$.

Далі властивості інформації сі, що має коефіцієнт важливості wi > 0,3, для прикладу, присвоїмо значення сі $=1,(\mathrm{i}=1)$, для властивостей ci 3 коефіцієнтом важливості $0,3>$ wi $\geq 0,06$ присвоїмо значення сі $=0,75(\mathrm{i}=2)$, для властивостей сі 3 коефіцієнтом важливості wi < 0,06 присвоїмо значення $\mathrm{ci}=0,5 ; \quad(\mathrm{i}=3)$. Тоді значення Z(x) узагальненого показника цінності 
інформації відповідного повідомлення х матиме вигляд:

$$
\mathrm{Z}(\mathrm{x})=0,666 \mathrm{x} 1+0,275 \mathrm{x} 0,75+0,058 \mathrm{x} 0,5=0,901 .
$$

Очевидно, що максимальне значення узагальненого показника цінності інформації буде при однаково важливих значеннях властивостей $\mathrm{w}_{\mathrm{i}}$, i високих значеннях показників самих властивостей, які характеризують інформацію $\mathrm{c}_{\mathrm{i}}$, $\left(\mathrm{Z}(\mathrm{x})_{\max }\right.$ наближатиметься до 1).

\section{Висновки й перспективи подальших досліджень}

Таким чином, запропоновано підхід вибору чисельного визначення властивостей інформації 3 точки зору ii безпеки за допомогою логіколінгвістичної моделі та методу попарних порівнянь. Він дозволяє отримати чисельне значення узагальненого показника цінності інформації як ресурсу, за допомогою якого оцінюється конфіденційна діяльність. Показник

\section{Лimepamypa}

1. Скриль С. В. Конфиденциальность как субъективный показатель защищенности информации / С. В. Скриль, А. П. Курило, В. Н. Финько, В. Н. Чашкин // Безопасность информационных технологий. 2009. Т. 16, Вип. № 3 C. 141-144. URL: https://bit.mephi.ru/index.php/bit/ article/view/865 (дата звернення: 17.08.2020). 2. Зарубин В. С. Некоторые подходы к оценке субъективных показателей качества защиты информации в автоматизированных комплексах физической защиты / В.С. Зарубин, Т.Б. Ходырев // Проблемы обеспечения безопасности при ликвидации последствий чрезвычайных ситуачий. 2015. Т. № 2, Вип. № 1 (4). C. 178-182. URL: https://cyberleninka.ru/article/n/ nekotorye-podhody-k-otsenke-subektivnyh-pokazateleykachestva-zaschity-informatsii-v-avtomatizirovannyh-

kompleksah-fizicheskoy (дата звернення: 17.08.2020). 3. Самохвалов Ю. Я. Оценка информационной безопасности организации по критерию уверенности / Ю. Я. Самохвалов, М. М. Браїловский // Захист інформаціï. 2019. Т. 21, Вип.№ 1. С. 13-24. URL: https://www.researchgate.net/publication/ 338160842 _Ocenka_informacionnoj_bezopasnosti__organizacii po_kriteriu_uverennosti (дата звернення: 17.08.2020). 4. Авсентьев А. О. Определение ценности информации // Управление, вычислительная техника и информатика: Доповіді ТУСУРа. 2016. Т. 19, № 1. С. 21-24. URL: https://cyberleninka.ru/article/n/ opredelenie-tsennostiinformatsii (дата звернення: 17.08.2020). 5. Авсентьев О. C. Формирование обобщенного показателя ценности информации в каналах связи / О. С. Авсентьев, А. О. Авсентьев, // Вісник Воронежского інституту МВC Pociï. 2015. Вип. № 3. С. 55-63. URL: https://cyberleninka.ru/article/n/formirovanieobobschennogo-pokazatelya-tsennosti-informatsii-v-
$\mathrm{Z}(\mathrm{x})$ може бути використаний як критерій для оцінки характеристик системи безпеки інформації.

Використання нечіткої логіки в обчисленнях узагальненого показника цінності відкриває нові можливості для оцінювання якості безпеки інформації, оскільки дає змогу оцінити якість не тільки з позиції того хто надає послуги щодо захисту інформації, але й 3 урахуванням поставлених вимог з боку споживача цих послуг. Використання узагальненого показника цінності інформації 3 точки зору безпеки інформації, експертам легше оцінити властивості інформації лінгвістичними термами а ніж числами.

Предметом подальших досліджень авторів $\epsilon$ розробка методики оцінки характеристик системи безпеки інформації за допомогою узагальненого показника цінності для задачі синтезу систем безпеки інформації із заданими властивостями.

kanalah-svyazi (дата звернення: 17.08.2020). 6. Авсентьев О. С. Моделирование и оптимизация процессов передачи и защиты информации в каналах связи / О. С. Авсентьев, В. В. Меньших, А. О. Авсентьев // Специальная техника. 2015. Вип. № 5. С. 47-50. URL: https://scholar.google.ru/citations?user=

CJxZf6YAAAAJ\&hl=ru (дата звернення: 17.08.2020). 7. Куцаєв В. В. Оцінка узагальненого показника цінності інформації при піi передачі в інформаційнотелекомунікаційній мережі / В. В. Куцаєв, М. М. Радченко, О. В. Драглюк, Р. А. Очіченко // Збірник наукових працьь ВITI. 2019. Вип. № 4. С 84-91. URL: http://www.viti.edu.ua/files/zbk/2019/9_4_2019.pdf (дата звернення: 17.08.2020). 8. Саати Т. Принятие решений. Метод анализа иерархий. М.: Радио и связь, 1993. 320 с. 9. Хрусталев Е. Ю. Логико-лингвистические модели наукоемкого производственного комплекса как разновидность интеллектуальных информационных систем // Теория экономического анализа. 2014. Вип. №11 (362). С 11-22. URL: https://cyberleninka.ru/ article/n/logiko-lingvisticheskie-modeli-naukoemkogoproizvodstvennogo-kompleksa-kak-raznovidnostintellektualnyh-informatsionnyh-sistem (дата звернення: 17.08.2020). 10. Чернов В. Г. Основы теории нечетких множеств: навч. посібник // В.Г. Чернов; Володимирський державний університет. Володимир: Видавництво Володимирського державного університету, 2010. 96 с. 11. Спиридонов С.Б. Анализ подходов к выбору весовых коэффициентов критериев методом парного сравнения критериев / С. Б. Спиридонов, И. Г. Булатова, В. М. Постников // Науковедение: Інтернет-журнал. 2017. Т. 9, Вип. №6 URL: https://naukovedenie.ru/PDF/16TVN617.pdf (дата звернення: 17.08.2020) 


\title{
ОПРЕДЕЛЕНИЕ ЧИСЛЕННОГО ЗНАЧЕНИЯ ОБОБЩЕННОГО ПОКАЗАТЕЛЯ ЦЕННОСТИ ИНФОРМАЦИИ С ТОЧКИ ЗРЕНИЯ ЕЕ БЕЗОПАСНОСТИ
}

\author{
Николай Николаевич Радченко \\ Алексей Викторович Драглюк ${ }^{1}$ \\ Михаил Михайлович Коротков ${ }^{1}$ \\ Александр Сергеевич Бидный \\ ${ }^{1}$ Военный институт телекомуникаций та информатизации имени Героев Крут, Киев, \\ Украина \\ ${ }^{2}$ Командование Войск связи Вооруженных Сил Украины, Киев, Украина
}

В разрезе обеспечения защчищенности информации в конкретных условиях возникает ряд трудностей, связанных с тем, что выбранные свойства информачии разнородные и не соизмеримы, не определены области допустимых значений характеристик и свойств защиты, которые являются производными от того что защищается и напрямую зависят от свойств самой информации, которые в свою очередь задаются владельцемм информации. Более того, представляет интерес с ичелью определения стоимостных величин защиты, определение количественных показателей свойств защиты.

Метрики информационной безопасности в соответствующих методиках, которые основаны на подходах верификации и риск-ориентирования недостаточно информативны, так как учитывают только объективные аспекты безопасности, абсолютно игнорируя субъективные. Они не позволяют выработать обоснованные суждения о состоянии конфиденциальности, целостности и доступности информации и уровне информаџионной безопасности организации в иелом. В связи с этим авторы предлагают подход к определению численного значения обобщенного показателя ценности информаџии на основе логико-лингвистической модели оценки свойств, характеризующих этот показатель, и метода попарных сравнений, который используется для определения численных значений коэффициентов важности выбраных свойств информации.

В данной работе предлагается подход решения задания касательно количественной оценки разнородных свойств информации и коэффициентов их значимости в интересах защиты информации, а также определения влияния свойств информации, которые задаются владельцем системы защиты информации на обобщенный показатель ценности информации. При этом для оценки численных значений рассмотренных свойств информаџии предлагается использование аппарата теории нечетких множеств, а определение соответствующих коэффициентов важности осуществляется с помощью метода анализа иерархий Саати.

Ключевые слова: свойство информаџчии; обобщенный показатель цченности информащии; коэффициент важности.

\section{DETERMINATION OF THE NUMERICAL VALUE OF A GENERALIZED INDICATOR OF THE VALUE OF INFORMATION FROM THE POINT OF VIEW OF ITS SECURITY}

\author{
Nikolay Radchenko ${ }^{1}$ \\ Oleksiy Dragluk ${ }^{1}$ \\ Mihael Korotkov ${ }^{1}$ \\ Olexandr Bidnyi ${ }^{2}$ \\ ${ }^{1}$ Heroes of Kruty Military Institute of Telecommunications and Informatization, Kyiv, Ukraine
${ }^{2}$ Signal and Cybersecurity Command of the Armed Forces of Ukraine, Kyiv, Ukraine
}

In the context of ensuring the security of information in specific conditions, a number of difficulties arise due to the fact that the selected properties of information are heterogeneous and not commensurate, the areas of acceptable values of characteristics and properties of protection are not defined, which are derived from what is protected and directly depend on the properties the information itself, which in turn are set by the owner of the information. Moreover, it is of interest for the purpose of determining the value of protection, the definition of quantitative indicators of the properties of protection.

Information security metrics in appropriate methodologies that are based on verification and riskorientation approaches are not sufficiently informative, since they take into account only objective aspects of security, completely ignoring subjective ones. They do not allow to make sound judgments about the state of confidentiality, integrity and accessibility of information and the level of information security of the organization as a whole. In this regard, the authors propose an approach to determine the numerical value of a generalized Modern Information Technologies in the Sphere of Security and Defence № 3(39)/2020 ISSN2311-7249(Print)/ISSN2410-7336(Onine) 
indicator of the value of information on the basis of the logico-linguistic model of evaluating the properties that characterize this indicator and the method of pairwise comparisons used to determine the numerical values of the coefficients of importance of these properties.

In this paper, we propose an approach for solving the task regarding the quantitative assessment of heterogeneous properties of information and the coefficients of their significance in the interests of information protection and to determine the influence of information properties that are set by the owner of the information security system on a generalized indicator of the value of information. At the same time, for the estimation of the numerical values of the considered properties of information, it is proposed to use the apparatus of the theory of fuzzy sets, and the determination of the corresponding coefficients of importance is carried out by the method of analysis of Saati hierarchies.

Key words: information property, generalized indicator of information value, importance factor.

\section{References}

1. Skril S.V., Kurilo A. P., Finko V.N. \& Chashkin V.N. (2009). Confidentiality as a subjective indicator of information security // Bezopasnost informatsionnyih tehnologiy, vol. 16, № 3, pp. 141-144, available at: https://bit.mephi.ru/index.php/bit/ article/view/865 [in Russian] 2. Zarubin V. S., Hodyirev T. B. (2015). Some approaches to the assessment of subjective indicators of information security in automated complexes of physical protection // Problemyi obespecheniya bezopasnosti pri likvidatsii posledstviy chrezvyichaynyih situatsiy, vol. № 2, № $1 \quad$ (4), $\quad$ pp. 178-182, available at: https:/cyberleninka.ru/article/n/ nekotorye-podhody-kotsenke-subektivnyh-pokazateley-kachestva-zaschityinformatsii-v-avtomatizirovannyh-kompleksah-fizicheskoy [in Russian] 3. Samokhvalov Y. Y., Brailovsky M. M. (2019) Assessment of information security of the organization by the criterion of confidence // Zakhyst informaciji, vol. 21, №1, pp. 13-24, available at: https://www.researchgate.net/

338160842_Ocenka_informacionnoj__bezopasnosti organizacii_ po_kriteriu_uverennosti [in Russian] $\overline{4}$. Avsentiev A. O. (2016) Determining the value of information // Upravlenie, vyichislitelnaya tehnika $i$ informatika. Vol. 19, Issue. № 1. Pp. 21-24, available at: https://cyberleninka.ru/article/n/ opredelenie-tsennostiinformatsii [in Russian] 5. Avsentiev O. S, Avsentiev A. O. (2015) Formation of the generalized indicator of value of information in channels of a holiday // Vestnik Voronezhskogo instituta MVS Rosii. Issue. № 3. Pp.55-63, available at: [in Russian] 6. Avsentiev O. S., Menshikh V.
V. \& Avsentiev A. O. (2015) Modeling and optimization of information transmission and protection processes in communication channels // Spetsialnaya tehnika, issue. № 5, pp. 47-50, available at: https://scholar.google.ru/ citations?user $=$ CJxZf6YAAAAJ\&hl=ru [in Russian $] 7$. Kutsaev V. V., Radchenko M. M., Draglyuk O. V. \& Ochichenko R. A. (2019) Estimation of the generalized indicator of value of information at its transfer in an information and telecommunication network // Zbirnyk naukovykh pracj VITI, issue. № 4, pp. 84-91, available at: http://www.viti.edu.ua/files/zbk/2019/9_4_2019.pdf [in Ukrainian] 8. Saati T. (1993) Decision making. Hierarchy analysis method. Moscov: Radio i svyaz, 320 [in Russian]. 9. Khrustalev E. Y. (2014) Logico-linguistic models of science-intensive production complex as a kind of intelligent information systems // Teoriya ekonomicheskogo analiza, issue №11 (362). pp. 11-22, available at: https://cyberleninka.ru/ article/n/logiko-lingvisticheskiemodeli-naukoemkogo-proizvodstvennogo-kompleksa-kakraznovidnost-intellektualnyh-informatsionnyh-sistem [in Russian] 10. Chernov V. G. (2010) Fundamentals of the theory of fuzzy sets: textbook. Manual. Vladimir: Izdatelstvo Vladimirovskogo gosudarstvennogo universiteta, 96. [in Russian] 11. Spiridonov S. B. , Bulatova I. G., \& Postnikov V. M. (2017) Analysis of approaches to the choice of weights of criteria by the method of pairwise comparison of criteria // Naukovedenie, vol. №9, №6, available at: https://naukovedenie.ru/PDF/ 16TVN617.pdf [in Russian]. 